\title{
Breeding for a more energy efficient greenhouse tomato: past and future perspectives
}

\author{
Anke van der Ploeg • Milan van der Meer • \\ Ep Heuvelink
}

Received: 7 December 2006/ Accepted: 6 April 2007/Published online: 28 April 2007

(C) Springer Science+Business Media B.V. 2007

\begin{abstract}
Energy efficiency can be increased either by increasing the production per $\mathrm{m}^{2}$ or by reducing the energy input per $\mathrm{m}^{2}$, e.g. by reducing temperature set-points in the greenhouse. So far, in Dutch glasshouse tomatoes energy efficiency was almost exclusively raised by yield increases. To study the role of tomato breeding in this production increase, yield and underlying components of 7 cultivars released between 1950 and 2002 were studied. Furthermore, variation in temperature response between cultivars was studied. In three experiments yield and biomass production of in total 11 cultivars were evaluated at two temperature regimes $\left(17 / 15^{\circ} \mathrm{C}\right.$ and $21 / 19^{\circ} \mathrm{C}$ day/night temperature set-points). Breeding has resulted in a remarkable increase in production. Under current conditions, yield of modern cultivars was on average $40 \%$ higher than yield of 'Moneymaker', released in 1950. This increase in production resulted from a higher light use efficiency. Although the fraction of assimilates partitioned to the fruits showed small differences between cultivars, this trait was not related to year of release. Furthermore, more recently introduced cultivars produced larger fruits rather than more fruits. All cultivars responded similar to both temperature regimes for all
\end{abstract}

A. van der Ploeg · M. van der Meer · E. Heuvelink ( $\square)$ Horticultural Production Chains Group, Wageningen University, Marijkeweg 22, 6709 PG Wageningen

The Netherlands

e-mail: ep.heuvelink@wur.nl important characteristics, limiting the possibilities of using existing cultivars in a breeding program for improved yield at lower temperatures.

Keywords Cultivar improvement · Energy efficiency · Harvest index - Light use efficiency · Temperature $\cdot$ Tomato

\section{Introduction}

Many horticultural crops, like tomato, originate from (sub)tropical areas. Especially at more northern latitudes high energy inputs are required to grow tomatoes in heated glasshouses. As both energy prices and public concern for environmental problems, caused by the emission of $\mathrm{CO}_{2}$, are rising, it is important that energy efficiency (the amount of product produced per unit energy input) increases. Over the past two decades energy efficiency in Dutch greenhouses has increased significantly almost exclusively as a result of higher production levels (Van der Knijff et al. 2004). Between 1980 and 2004 tomato production gradually increased from 18 to $50 \mathrm{~kg} \mathrm{~m}^{-2}$ (KWIN 1998; CBS 2006). This increase in yield is partly the result of changes in cultivation techniques (e.g. growing on substrate, supply of $\mathrm{CO}_{2}$, extended cropping season) and technical measures (e.g. use of climate computers, higher greenhouse transmissivity) but this gain can also be partly attributed to the work of plant breeders who developed higher yielding 
cultivars. For breeders, to produce cultivars with further yield improvements, it is important to realize how breeding has affected yield in the past. Yield is the product of total biomass production and the partitioning of assimilate towards harvestable organs (harvest index). In most cereal crops yield increases by genetic improvement could be ascribed to an increased harvest index (Hay 1995). For example, in barley increased yields in cultivars introduced between 1900 and 1980 were mainly the result of an increase in harvest index from 0.36 to 0.48 (Hay 1995). However, in maize (Hay 1995) and lentil (Whitehead et al. 2000) increased yield could be ascribed to increased biomass production. To what extent and in which way breeding has contributed to increased yield in tomato is so far not known.

Another possibility to further increase energy efficiency of greenhouse tomato is by reducing the greenhouse air temperature, thus reducing the amount of energy used per $\mathrm{m}^{2}$. Decreasing the temperature set-point by $2^{\circ} \mathrm{C}$ could potentially result in an energy saving of $16 \%$ (Elings et al. 2005). However, reducing air temperature has several unfavorable effects on production, e.g. a delay in harvest and lower (early) yields (Hurd and Graves 1985; Adams et al. 2001). To overcome these adverse effects of low temperature new cultivars have to be developed. Genetic variation in temperature response is essential as a basis for cultivar improvement. Previous studies on young plants have shown that the variation in temperature response between tomato cultivars is limited (Paul et al. 1984; Smeets and Garretsen 1986) but information about the variation in temperature response on yield is scarce (Van der Ploeg and Heuvelink 2005). Khayat et al. (1985) found that the yield of 'Moneymaker' was reduced when night temperature set-point was $12^{\circ} \mathrm{C}$ instead of $18^{\circ} \mathrm{C}$ to $12^{\circ} \mathrm{C}$, while yield of the cultivar 'Cherry $35070 \mathrm{E}$ Danmark' was unaffected by this reduction in night temperature. However, it is not clear whether in 'Moneymaker' total biomass production, partitioning, or both were affected. If there is variation in temperature response it is important to know which underlying processes are responsible for differences between cultivars.

The aim of this paper is to determine to what extent and in which way breeding has affected yield in tomato over the past 50 years. Furthermore several modern cultivars are evaluated for possible differences in temperature response and the underlying physiological and morphological factors, that can explain these possible differences, are studied.

\section{Materials and methods}

\section{Experimental set-up}

Three experiments (Table 1) were conducted in three successive years in two compartments $(12 \mathrm{~m} \times 12.8 \mathrm{~m})$ that were part of a multispan Venlo-type greenhouse (Wageningen University, The Netherlands, lat. $52^{\circ} \mathrm{N}$ ). The cultivars used in Expts 1 and 2 were expected to respond differently to temperature based on preliminary work. In Expt 3 a selection was made from several older and more recent cultivars (Table 1). Seeds were sown in trays filled with commercial potting soil on dates indicated in Table 1. About 14 days after sowing seedlings were pricked out and transferred to rockwool cubes and placed on ebb/flood benches in another compartment of the same greenhouse. About 2 weeks before anthesis of the first truss, plants were transferred to the cultivation compartments and placed on rockwool slabs at a plant density of 2.5 plants $\mathrm{m}^{-2}$. Each compartment contained two plots of each cultivar (20 plants per plot). At anthesis of the first flowers the temperature in each greenhouse compartment was set at the desired level. All axillary shoots were removed weekly and plants were trained according to the high wire system (Peet and Welles 2005). Old leaves below the lowest ripening truss were removed weekly. Plant nutrition and pest and disease control were conducted according to common practice. Flowers were pollinated by bumblebees.

\section{Greenhouse climate}

Heating set-points for day/night were $17 / 15^{\circ} \mathrm{C}$ (low temperature treatment; LT) and $21 / 19^{\circ} \mathrm{C}$ (high temperature treatment; HT). Ventilation set-points were $1^{\circ} \mathrm{C}$ above the heating set-points. Greenhouse climate was automatically recorded every $5 \mathrm{~min}$ using a commercial computer system (Hoogendoorn, Vlaardingen, The Netherlands). Daily global radiation 
Table 1 Basic information on the three greenhouse experiments
Dates are expressed as day

of the year (day $1=1$

January)

a Averaged over the whole cultivation period

b $24 \mathrm{~h}$ average greenhouse temperature, averaged over the whole cultivation period

c Year of release of each cultivar is given between brackets

\begin{tabular}{|c|c|c|c|}
\hline & \multicolumn{3}{|l|}{ Experiment } \\
\hline & 1 & 2 & 3 \\
\hline Year & 2002 & 2003 & 2004 \\
\hline Sowing date & 334 & 327 & 353 \\
\hline Start date & 28 & 20 & 48 \\
\hline End date & 155 & 142 & 172 \\
\hline 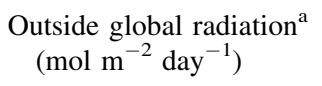 & 53.4 & 51.1 & 63.1 \\
\hline \multirow[t]{2}{*}{ Temperature $^{\mathrm{b}}\left({ }^{\circ} \mathrm{C}\right)$} & LT: 18.5 & LT: 18.5 & LT: 19.6 \\
\hline & HT: 21.2 & HT: 20.9 & HT: 21.3 \\
\hline \multirow[t]{7}{*}{ Cultivars $^{c}$} & Counter (1985) & Capita (1992) & Moneymaker (1950) \\
\hline & Pronto (1990) & Chaser (1992) & Extase (1960) \\
\hline & Chaser (1992) & Prospero (1997) & Calypso (1982) \\
\hline & Prospero (1997) & & Liberto (1988) \\
\hline & & & Gourmet (1991) \\
\hline & & & Chaser (1992) \\
\hline & & & Encore (2002) \\
\hline
\end{tabular}

outside the greenhouse was obtained from the department of meteorology at about $800 \mathrm{~m}$ distance. Realized average temperature and radiation are given in Table 1.

\section{Measurements}

Destructive measurements were carried out at anthesis, at the end of the experiment and two times during the experiment, resulting in more or less equal time intervals between measurements. At each destructive harvest two plants per plot were measured, except for the final harvest, when four plants per plot were taken. Fresh and dry mass (ventilated oven; at least $10 \mathrm{~h}$ at $105^{\circ} \mathrm{C}$ ) from leaves (including petioles), stem, fruit trusses, removed leaves and picked fruits and leaf area (LI-COR Model 3100 Area Meter) were determined. Number of leaves $(>0.5 \mathrm{~cm})$, number of trusses $(>0.5 \mathrm{~cm})$ and number of fruits $(>0.5 \mathrm{~cm})$ were recorded. The plants used for destructive measurements were surrounded by guard plants. Extra side shoots were allowed to grow on guard plants to replace measured plants in order to maintain stem density and light distribution in the crop.

Light use efficiency

For each treatment a time course of leaf area index (LAI), based on linear interpolations between destructive leaf area measurements, was calculated. Based on measured daily global radiation, a greenhouse transmissivity of $69 \%$, assuming $47 \%$ photosynthetic active radiation (PAR) in the global radiation, and a light extinction coefficient of the canopy of 0.75 (Heuvelink and Buiskool 1995) the daily intercepted PAR by the crop was calculated. Light use efficiency (LUE) was calculated as the dry matter production divided by the integral of intercepted PAR over a period between two destructive measurements. LUE was averaged over three periods resulting from four destructive harvests.

\section{Statistical analysis}

In all experiments a split-plot design was used, with temperature as the main plot and cultivars as the split factor. With only two compartments each undergoing a different temperature regime there is no true replication for temperature in this experiment, so variability between plots within compartments has been used as a proxy error. Data were checked for normality using the 'Kolmogorov-Smirnov' test (SPSS 12.0). Analysis of variance was conducted, using Genstat 8, and treatment effects were tested at $5 \%$ probability level, except for the temperature effect which was tested at $10 \%$ probability level due to the low degrees of freedom of the residual. Mean separation was done by Student's $t$-test $(P=0.05)$. 


\section{Results}

Although there were clear cultivar and temperature effects, none of the experiments showed an interaction between temperature and cultivar for any important characteristic. Therefore, the effects of temperature and cultivar on growth and yield are presented separately.

\section{Temperature effects}

In all experiments fruits grown at HT had a significantly shorter fruit growth period (Table 2) and therefore plants grown at HT produced earlier ripe fruits than plants grown at LT (Fig. 1). Hence, during early phases of the cultivation cumulative yield was higher at HT (Fig. 1). However, once harvesting had started at LT, heavier fruits could be picked at LT and consequently cumulative yield increased more rapidly at LT. Therefore, in Expts 1 and 3 no differences were present in yield between the two temperature treatments at final harvest stage (Table 2). Only in Expt 2 cumulative yield was still higher at HT, but as the slope of yield against time was higher at LT (Fig. 1) it is expected that if Expt 2 would have lasted longer yield differences between HT and LT would also disappear. In all experiments the cumulative number of fruits harvested was significantly higher at HT (Table 2).

Table 2 The effect of temperature in three experiments on fruit growth period (FGP; number of days between anthesis and harvesting of first fruits per truss) of the first three trusses, total cumulative yield fresh $\left(\right.$ Yield $\left._{\mathrm{FW}}\right)$ and dry weight $\left(\right.$ Yield $\left._{\mathrm{DW}}\right)$, total number of harvested fruits $\left(\mathrm{NoF}_{\text {harvest }}\right)$, average fruit mass

\begin{tabular}{|c|c|c|c|c|c|c|c|c|c|}
\hline Exp. & Temp. & $\begin{array}{l}\text { FGP } \\
\text { (day) }\end{array}$ & $\begin{array}{l}\text { Yield }_{\mathrm{FW}} \\
\left(\mathrm{kg} \mathrm{m}^{-2}\right)\end{array}$ & $\begin{array}{l}\text { Yield }_{\text {DW }} \\
\left(\mathrm{kg} \mathrm{m}^{-2}\right)\end{array}$ & $\begin{array}{l}\text { NoF } \\
\left(\mathrm{m}^{-2}\right)\end{array}$ & 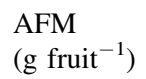 & FDMC & $\begin{array}{l}\text { TDM } \\
\left(\mathrm{kg} \mathrm{m}^{-2}\right)\end{array}$ & $\mathrm{FF}$ \\
\hline \multirow[t]{3}{*}{1} & $\mathrm{LT}$ & $75 \mathrm{~b}$ & 9.6 & 0.44 & $148 \mathrm{a}$ & $3.02 \mathrm{~b}$ & $0.050 \mathrm{a}$ & 1.35 & 0.586 \\
\hline & HT & $54 \mathrm{a}$ & 8.8 & 0.44 & $183 \mathrm{~b}$ & $2.46 \mathrm{a}$ & $0.055 \mathrm{~b}$ & 1.27 & 0.582 \\
\hline & $F$-prob. ${ }^{\mathrm{a}}$ & 0.007 & 0.243 & 0.840 & 0.031 & 0.012 & 0.010 & 0.141 & 0.757 \\
\hline \multirow[t]{3}{*}{2} & $\mathrm{LT}$ & $78 \mathrm{~b}$ & $7.5 \mathrm{a}$ & $0.40 \mathrm{a}$ & $105 \mathrm{a}$ & $3.90 \mathrm{~b}$ & 0.053 & 1.24 & 0.598 \\
\hline & HT & $58 \mathrm{a}$ & $9.0 \mathrm{~b}$ & $0.47 \mathrm{~b}$ & $163 \mathrm{~b}$ & $2.90 \mathrm{a}$ & 0.052 & 1.25 & 0.604 \\
\hline & $F$-prob. $^{\text {a }}$ & 0.005 & 0.060 & 0.094 & 0.010 & 0.019 & 0.518 & 0.937 & 0.636 \\
\hline \multirow[t]{3}{*}{3} & $\mathrm{LT}$ & $74 \mathrm{~b}$ & 11.9 & 0.56 & $169 \mathrm{a}$ & $3.34 \mathrm{~b}$ & $0.051 \mathrm{a}$ & 1.54 & 0.578 \\
\hline & HT & $58 \mathrm{a}$ & 11.3 & 0.58 & $183 \mathrm{~b}$ & $3.12 \mathrm{a}$ & $0.055 \mathrm{~b}$ & 1.50 & 0.568 \\
\hline & $F$-prob. ${ }^{\text {a }}$ & 0.014 & 0.348 & 0.732 & 0.088 & 0.096 & 0.016 & 0.455 & 0.240 \\
\hline
\end{tabular}

Values are averages over 4, 3 and 7 cultivars for Expts 1, 2 and 3, respectively

a $F$-probability (significant levels $<0.10$ presented in bold). Different letters within an experiment indicate significant differences between treatments based on Student's $t$-test $(P=0.10)$
Furthermore, in Expts 1 and 3 fruits produced at HT had a higher dry matter content than fruits grown at LT. In Expt 2 no effect of temperature on fruit dry matter content was observed.

Total dry matter (TDM) production and the fraction of assimilates distributed towards the fruits over the whole cultivation period were unaffected by temperature (Table 2). Although overall partitioning was not affected by temperature, during the first six weeks after anthesis the fraction of assimilates distributed towards the fruits was significantly higher at HT (Fig. 2). Contrary, during the last six weeks of the experiment distribution of assimilates towards the fruits was significantly higher at LT (Fig. 2). Fruit load (measured as the number of fruits on the plant) at the second destructive measurement was higher at HT while at the third destructive harvest fruit load was equal at both temperatures in Expt 2, while in Expts 1 and 3 it was higher at LT (Fig. 3). At the final destructive measurement fruit load was higher at LT in Expts 1 and 2 while it was equal for both temperatures in Expt 3.

Temperature had a strong influence on development (Table 3). At HT more leaves and trusses were produced than at LT and as a consequence stem length was also higher at HT. However, although the number of trusses was higher at HT, the total number of fruits produced was unaffected by temperature in Expts 1 and 3.

of harvested fruits (AFM), fruit dry matter content (FDMC) of harvested fruits, total plant biomass (TDM) and the fraction of assimilates partitioned to the fruits (FF) at the final harvest stage 


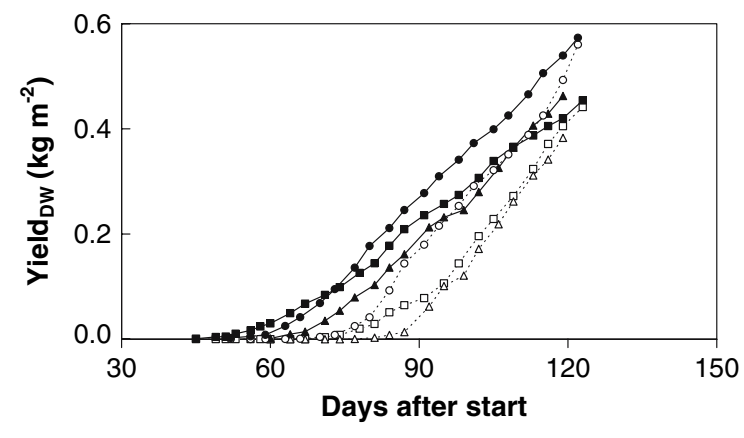

Fig. 1 Cumulative yield dry weight of tomato grown at LT ( $-\square \triangle \bigcirc_{-}$) or HT (- $\mathbf{\square} \mathbf{\Delta} \mathbf{O}_{-}$) as a function of days after start of the temperature treatments, averaged over 4,3 or 7 cultivars in Expt $1(\boldsymbol{\square}, \square)$, Expt $2(\boldsymbol{\Lambda}, \triangle)$ and $\operatorname{Expt} 3(\boldsymbol{\bullet}, \bigcirc)$ respectively

\section{Cultivar effects}

Cultivars differed in fruit growth period but this was not related to the year of release. Significant differences in total yield between cultivars were only present in Expt 3 (Table 4). The two oldest cultivars, 'Moneymaker' and 'Extase' had a significantly lower yield than the cultivars released after 1982. Within the five cultivars that were released after 1982 no significant differences in yield were present. On average these cultivars produced a $41 \%$ and $22 \%$ higher yield dry weight than 'Moneymaker' and 'Extase', respectively. In Expts 1 and 3 cultivars also differed in fruit size and number (Table 4). In general fruits of modern cultivars were larger than fruits of the older cultivars. The two newest cultivars 'Chaser' and 'Encore' produced the largest fruits, while the smallest fruits were produced by 'Moneymaker' and 'Extase'. Within the modern cultivars, the cultivars which produced a lower number of fruits showed a higher average fruit size. Only in Expt 3 significant differences were present between cultivars in dry matter content of harvested fruits. Dry matter content ranged between $5.0 \%$ for 'Encore' and $5.5 \%$ for 'Moneymaker' and 'Gourmet'. Dry matter content of the fruits was negatively correlated with fruit size $\left(r^{2}=0.72\right)$.

At the end of Expt 1 there were differences in TDM and distribution of assimilates towards the fruits. For 'Pronto' TDM was lower than for the other cultivars. Larger differences in TDM were present in Expt 3, 'Moneymaker' and 'Extase' produced 19\% and $13 \%$ less TDM than the five cultivars released after 1982. Yield was positively correlated with TDM
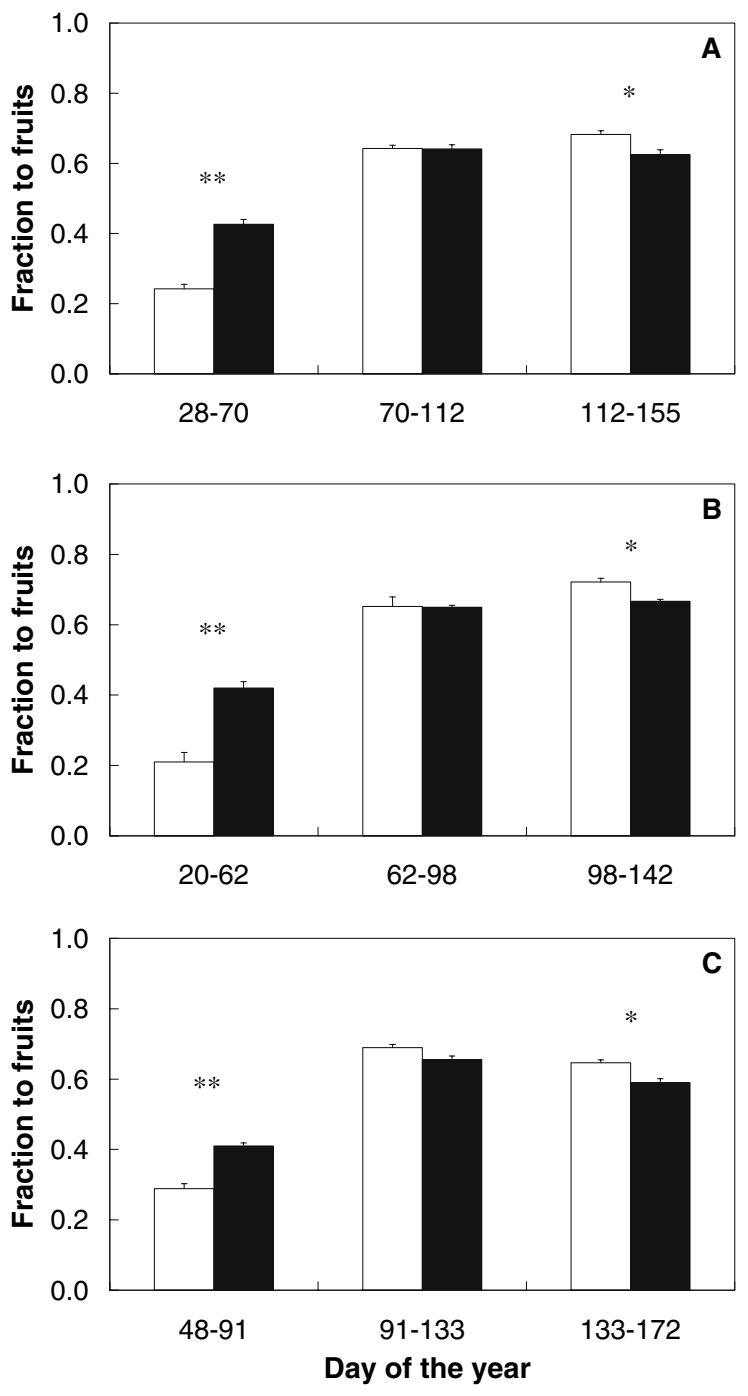

Fig. 2 Fraction of total above-ground dry matter distributed to the fruits between destructive harvests of tomato grown at LT (open bars) and HT (closed bars) averaged over 4, 3 or 7 cultivars in Expt 1 (A), Expt 2 (B) and Expt 3 (C), respectively. Vertical bars are standard errors of mean. *indicates significant differences at $P=0.05$ and $* * P=0.01$

$\left(r^{2}=0.86\right)$. To determine whether the increase in TDM was a result of increased light interception or whether light was used more efficiently, the LUE was calculated. Both 'Moneymaker' and 'Extase' had a lower LUE than the more recently released cultivars. Moreover, LUE showed a linear increase with year of release (Fig. 4). Small, but significant differences were also present between cultivars in partitioning towards the fruits but these differences were unrelated to year of release. In 'Encore' $55 \%$ of the 

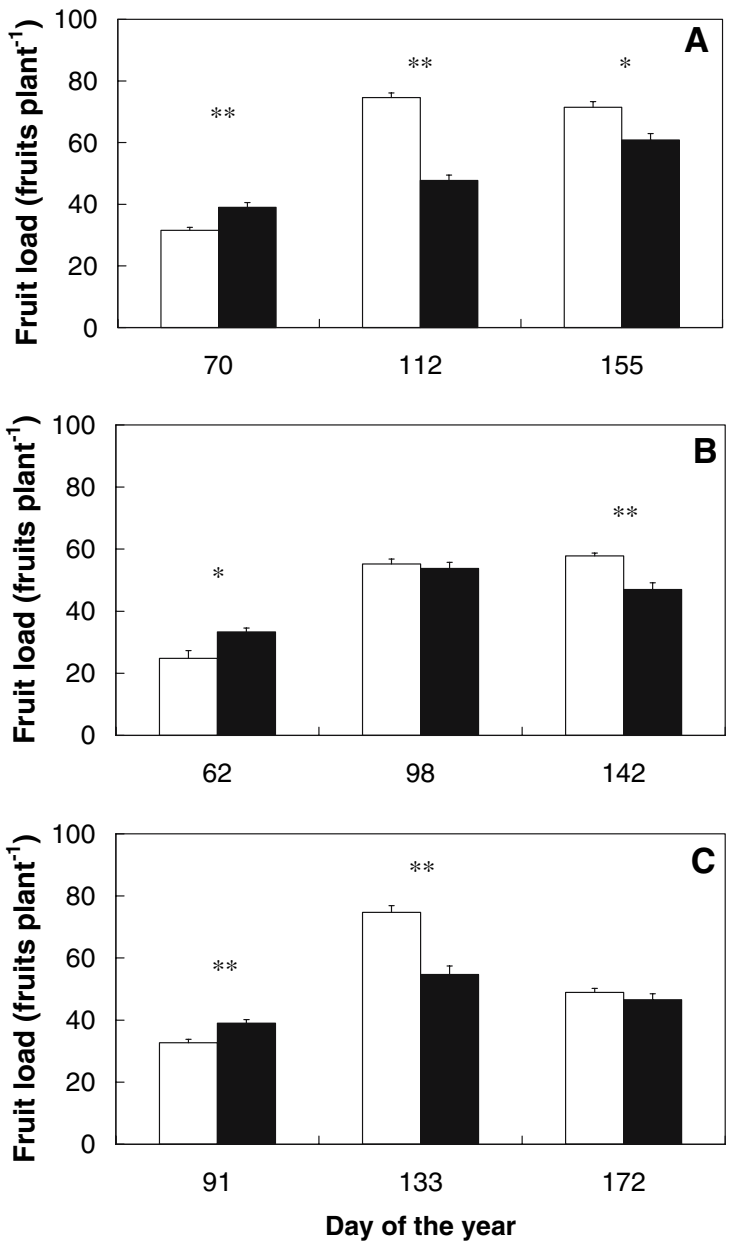

Fig. 3 Fruit load (number of fruits per plant) of tomato grown at LT (open bars) and HT (closed bars) averaged over 4, 3 or 7 cultivars in Expt 1 (A), Expt 2 (B) and Expt 3 (C), respectively. Vertical bars are standard errors of mean. *indicates significant differences at $P=0.05$ and $* * P=0.01$

assimilates were distributed towards the fruits while in 'Liberto' almost $60 \%$ of the assimilates went to the fruits. Assimilate partitioning was negatively correlated with fruit growth period $\left(r^{2}=0.73\right)$.

Clear differences were also present between cultivars in stem length and number of trusses in Expts 1 and 3 (Table 5). However, the cultivars with longer stems were not always the cultivars with the higher number of leaves (internodes), thus clearly showing that differences between cultivars were related both to leaf number and internode length. Small but statistically significant differences were also present in the total number of fruits produced by each cultivar.

\section{Discussion}

Cultivar improvement over the past 50 years

Tomato breeding has contributed substantially to increased yield and biomass production. The five cultivars released after 1982 produced 32 to $47 \%$ higher yields (dry weight) than 'Moneymaker', the oldest cultivar used in this study (Table 4). Higher yields were a consequence of an increase in TDM due to higher LUEs (Fig. 4). It is therefore likely that the photosynthetic capacity of tomato has increased as well, although more research will be necessary to confirm this. Also in soybean the photosynthetic rate was increased in modern cultivars compared to older cultivars (Morrison et al. 1999). Another possibility is that light interception (e.g. leaf angle distribution, light extinction coefficient) has changed.

These results illustrate the direction of tomato breeding over the past 50 years. Initially breeders mainly focused on increasing yield, but as the demand for higher quality fruit increased, the focus has shifted towards characteristics that reduce production costs or ensure reliable production of high yields of high quality fruits (Ho 1996b; Lindhout 2005). Breeding during the past decades has also led to the progressive introduction of resistance genes from related wild Lycopersicon species. For instance, the introduction of TMV resistant varieties gave a remarkable production increase in the early 1970s (Van de Vooren et al. 1986) and yields of 'Moneymaker' and 'Extase', the only two cultivars susceptible to TMV in this study, would have been even lower if plants would have been infected with TMV.

Although TDM in 'Moneymaker' and 'Extase' was lower than in the modern cultivars, the total number of fruits produced (both harvested and green fruits) was similar to that of the modern cultivars (Table 4). The higher assimilate supply in modern cultivars resulted solely in considerably larger fruits. As the fruit growth period was not related to year of release, the increase in fruit size must rely on larger cell division and/or cell expansion rates. Cell expansion rates could be influenced by the ploidy levels within the tomato fruit pericarp. Cheniclet et al. (2005) showed that within a selection of cultivars, covering a wide range of fruit sizes, fruit mass correlates positively with mean cell size and ploidy level. Ho (1996a) suggested harvest index could be 
Table 3 The effect of temperature on stem length, total number of leaves produced (NoL), number of trusses (NoT) and total number of fruits produced $(\mathrm{NoF})$ per plant at the final harvest stage

\begin{tabular}{|c|c|c|c|c|c|}
\hline Exp. & Temperature & Stem length $(\mathrm{cm})$ & NoL $\left(\right.$ plant $\left.^{-1}\right)$ & NoT (plant ${ }^{-1}$ ) & $\mathrm{NoF}\left(\right.$ plant $\left.^{-1}\right)$ \\
\hline \multirow[t]{3}{*}{1} & LT & $491 \mathrm{a}$ & $63 \mathrm{a}$ & $17.0 \mathrm{a}$ & 130 \\
\hline & HT & $598 \mathrm{~b}$ & $72 \mathrm{~b}$ & $20.5 \mathrm{~b}$ & 133 \\
\hline & $F$-prob. $^{\text {a }}$ & 0.007 & 0.006 & 0.009 & 0.612 \\
\hline \multirow[t]{3}{*}{2} & LT & $419 \mathrm{a}$ & $52 \mathrm{a}$ & $13.5 \mathrm{a}$ & $99 \mathrm{a}$ \\
\hline & HT & $533 \mathrm{~b}$ & $63 \mathrm{~b}$ & $17.5 \mathrm{~b}$ & $112 \mathrm{~b}$ \\
\hline & $F$-prob. $^{\text {a }}$ & 0.024 & 0.016 & 0.003 & 0.020 \\
\hline \multirow[t]{3}{*}{3} & LT & $492 \mathrm{a}$ & 63 a & $16.6 \mathrm{a}$ & 117 \\
\hline & HT & $550 \mathrm{~b}$ & $69 \mathrm{~b}$ & $18.9 \mathrm{~b}$ & 120 \\
\hline & $F$-prob. ${ }^{\mathrm{a}}$ & 0.001 & 0.019 & 0.006 & 0.172 \\
\hline
\end{tabular}

Values are averages over 4, 3 and 7 cultivars for Expts 1, 2 and 3, respectively

a $F$-probability (significant levels $<0.10$ presented in bold). Different letters within an experiment indicate significant differences between treatments based on Student's $t$-test $(P=0.10)$

improved effectively by increasing the fruit size. Although breeding did effectively increase fruit size, harvest index was not increased. In this study only round tomato cultivars were used. Perhaps larger differences in harvest index could exist between different types of tomato (e.g. cherry, round, beafsteak). In fact, Ho (1996a) found differences in yield between different indeterminate types of tomato that were related to differences in harvest index. However, Ho (1996a) only measured partitioning 112 days after sowing; differences in yield and harvest index could thus be caused by to differences in development rate (earliness) between different types of tomato cultivars. In fact, dry matter partitioning in Expt 3 was negatively correlated with fruit development rate.

Although there were small differences between cultivars in partitioning towards the fruits, surprisingly harvest index was not related to year of release. This is in contrast to several temperate cereals where improvement in grain yield could be ascribed to a progressive increase in harvest index since 1900 (Hay 1995). The introduction of dwarfing genes increased grain yield at the expense of straw biomass (Milach and Federizzi 2001). However, in tomato the fraction of assimilates that was partitioned towards the stems was already relatively small in 'Moneymaker' (14\%, data not shown) and was not significantly affected by genotype. Moreover, the indeterminate growth pattern of greenhouse tomato cultivars necessitates that a certain amount of assimilates is partitioned towards the stem as new internodes need to support future leaves and trusses.

\section{Temperature effects}

Temperature was not constant during the experiments. At the start of the experiments clear temperature differences could be realized between the HT and LT compartments, but later in the season, due to higher solar radiation, it was more difficult to keep the temperature in the compartments at the desired level. Therefore towards the end of the experiment temperature differences were small. Especially in Expt 3, which started one month later than the other two experiments, the overall average temperature difference was rather small. This however did not prohibit profound differences between the temperature treatments in timing of yield and partitioning. De Koning (1989) also showed that clear differences in fruit growth and fruit load remained, when temperatures were kept equal after four different temperature treatments $\left(17-23^{\circ} \mathrm{C}\right)$ had been applied for 8 weeks.

Initially partitioning towards the fruits was higher at HT (Fig. 3). Partitioning is not influenced by temperature directly but indirectly through the influence of temperature on development rate, flower and fruit abortion (Heuvelink 1995). As a consequence of an increasing truss appearance rate with temperature (De Koning 1994; Adams et al. 2001) there were initially more fruits on the plant at HT 
Table 4 Cultivar effect in three experiments on fruit growth period (FGP; number of days between anthesis and harvesting of first fruits per truss) of the first three trusses, total cumulative yield fresh $\left(\right.$ Yield $\left._{\mathrm{FW}}\right)$ and dry weight $\left(\right.$ Yield $\left._{\mathrm{DW}}\right)$, total number of harvested fruits $\left(\mathrm{NoF}_{\text {harvest }}\right)$, average fruit mass (AFM), dry matter content of harvested fruits (FDMC), total plant biomass (TDM) and the fraction of assimilates in the fruits (FF) at final harvest stage

\begin{tabular}{|c|c|c|c|c|c|c|c|c|c|}
\hline Exp. & Cultivar & $\begin{array}{l}\text { FGP } \\
\text { (day) }\end{array}$ & $\begin{array}{l}\text { Yield }_{\mathrm{FW}} \\
\left(\mathrm{kg} \mathrm{m}^{-2}\right)\end{array}$ & $\begin{array}{l}\text { Yield }_{\text {DW }} \\
\left(\mathrm{kg} \mathrm{m}^{-2}\right)\end{array}$ & $\begin{array}{l}\mathrm{NoF}_{\text {harvest }} \\
\left(\mathrm{m}^{-2}\right)\end{array}$ & $\begin{array}{l}\text { AFM } \\
\text { (g fruit }^{-1} \text { ) }\end{array}$ & FDMC & $\begin{array}{l}\text { TDM } \\
\left(\mathrm{kg} \mathrm{m}^{-2}\right)\end{array}$ & $\mathrm{FF}$ \\
\hline \multirow[t]{5}{*}{1} & Counter & $61 \mathrm{a}$ & 9.4 & 0.46 & $185 \mathrm{c}$ & $2.54 \mathrm{a}$ & 0.053 & $1.32 \mathrm{~b}$ & $0.600 \mathrm{~b}$ \\
\hline & Pronto & $63 \mathrm{~b}$ & 8.9 & 0.43 & $169 \mathrm{~b}$ & $2.53 \mathrm{a}$ & 0.052 & $1.23 \mathrm{a}$ & $0.598 \mathrm{~b}$ \\
\hline & Chaser & $66 \mathrm{c}$ & 9.2 & 0.45 & $151 \mathrm{a}$ & $3.02 \mathrm{~b}$ & 0.053 & $1.37 \mathrm{~b}$ & $0.570 \mathrm{a}$ \\
\hline & Prospero & $67 \mathrm{c}$ & 9.4 & 0.44 & $155 a b$ & $2.88 \mathrm{~b}$ & 0.051 & $1.33 \mathrm{~b}$ & $0.568 \mathrm{a}$ \\
\hline & $F$-prob. ${ }^{\mathrm{a}}$ & $<0.001$ & 0.435 & 0.145 & 0.004 & $<0.001$ & 0.075 & 0.032 & 0.002 \\
\hline \multirow[t]{4}{*}{2} & Capita & $66 \mathrm{a}$ & 8.3 & 0.45 & 140 & 3.33 & 0.054 & 1.28 & 0.606 \\
\hline & Chaser & $67 \mathrm{a}$ & 7.9 & 0.41 & 123 & 3.43 & 0.052 & 1.23 & 0.589 \\
\hline & Prospero & $70 \mathrm{~b}$ & 8.6 & 0.45 & 133 & 3.48 & 0.053 & 1.21 & 0.607 \\
\hline & $F$-prob. ${ }^{\text {a }}$ & 0.002 & 0.497 & 0.234 & 0.065 & 0.534 & 0.643 & 0.308 & 0.110 \\
\hline \multirow[t]{8}{*}{3} & Moneymaker & $65 \mathrm{ab}$ & $8.5 \mathrm{a}$ & $0.43 \mathrm{a}$ & $163 a b$ & $2.64 \mathrm{a}$ & $0.055 \mathrm{~d}$ & $1.29 \mathrm{a}$ & $0.579 \mathrm{~cd}$ \\
\hline & Extase & $69 \mathrm{~cd}$ & $10.2 \mathrm{~b}$ & $0.50 \mathrm{~b}$ & $175 \mathrm{bc}$ & $2.87 \mathrm{ab}$ & $0.054 \mathrm{c}$ & $1.39 \mathrm{a}$ & $0.570 \mathrm{abc}$ \\
\hline & Calypso & $66 \mathrm{bc}$ & $12.2 \mathrm{c}$ & $0.61 \mathrm{c}$ & $178 \mathrm{bc}$ & $3.44 \mathrm{de}$ & $0.053 \mathrm{c}$ & $1.55 \mathrm{~b}$ & $0.572 \mathrm{bc}$ \\
\hline & Liberto & $62 \mathrm{a}$ & $12.6 \mathrm{c}$ & $0.61 \mathrm{c}$ & $188 \mathrm{~cd}$ & $3.23 \mathrm{~cd}$ & $0.052 \mathrm{~b}$ & $1.54 \mathrm{~b}$ & $0.598 \mathrm{~d}$ \\
\hline & Gourmet & $63 \mathrm{ab}$ & $12.3 \mathrm{c}$ & $0.62 \mathrm{c}$ & $199 \mathrm{~d}$ & $3.12 \mathrm{bc}$ & $0.055 \mathrm{~d}$ & $1.59 \mathrm{~b}$ & $0.586 \mathrm{~cd}$ \\
\hline & Chaser & $66 \mathrm{bc}$ & $13.1 \mathrm{c}$ & $0.63 \mathrm{c}$ & $175 \mathrm{bc}$ & $3.60 \mathrm{ef}$ & $0.052 \mathrm{~b}$ & $1.68 \mathrm{~b}$ & $0.557 \mathrm{ab}$ \\
\hline & Encore & $70 \mathrm{~d}$ & $12.5 \mathrm{c}$ & $0.57 \mathrm{c}$ & $155 \mathrm{a}$ & $3.71 \mathrm{f}$ & $0.050 \mathrm{a}$ & $1.61 \mathrm{~b}$ & $0.550 \mathrm{a}$ \\
\hline & $F$-prob. $^{\mathrm{a}}$ & 0.001 & 0.001 & 0.001 & 0.005 & $<0.001$ & $<0.001$ & 0.001 & 0.003 \\
\hline
\end{tabular}

Values are the averages for 2 temperature regimes

a $F$-probability (significant levels $<0.05$ presented in bold). Different letters within an experiment indicate significant differences between treatments based on Student's $t$-test $(P=0.05)$

(Fig. 3) and a higher number of fruits on the plant favors partitioning towards the fruits (Heuvelink 1997). However, early fruit will grow at the expense of vegetative parts and as developing and flowering trusses are weaker sinks than fruiting trusses (Ho and Hewitt 1986) this may also cause a delay in growth of newly set fruits and might even lead to flower or fruit abortion (De Koning 1989). At the second and final destructive measurements the fruit load was either higher at LT or equal at both temperature regimes, resulting in increased partitioning towards the fruits in the last six weeks of the experiment (Fig. 3). The overall partitioning during the experiment was not affected by temperature (Table 2). However, if temperature set-points would be decreased further, fruit and seed set could be affected. Adams et al. (2001) found that fruits grown at $14^{\circ} \mathrm{C}$ were parthenocarpic and attracted less assimilates than fruits grown at either $18^{\circ} \mathrm{C}$ or $22^{\circ} \mathrm{C}$.

As TDM was not affected by temperature and partitioning approached a functional balance, the yield on the long run was not reduced at LT. Thus, focusing solely on the cumulative yield, there is no reason why temperature could not be reduced in the greenhouse. However, as early yield is more profitable, because of higher prices early in the season, it might not be economically feasible to reduce temperatures in the greenhouse. This, of course, depends very much on the amount of energy that can be saved and the energy and product prices. Hurd and Graves (1985) calculated that in 1980 it was not profitable to reduce greenhouse night temperature from $16^{\circ} \mathrm{C}$ to $11^{\circ} \mathrm{C}$ although it almost halved the energy costs.

Breeding for cultivars with a lower temperature demand

The lack of variation between cultivars in temperature response illustrates the limited genetic variation between tomato cultivars, which is typical of selfpollinating crops, where domestication and breeding took place outside the native area (Rick and Chetelat 


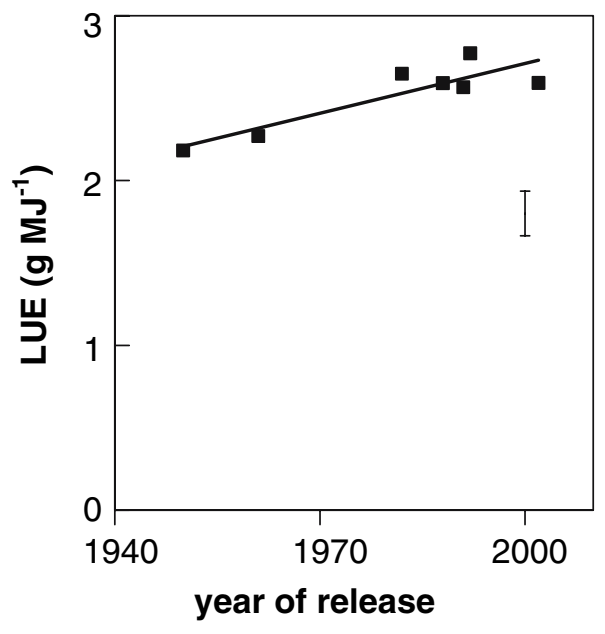

Fig. 4 Light use efficiency (LUE) over the whole growth period as a function of the year of release of tomato cultivars. Values are averaged over 2 temperature regimes (Expt 3). Line represent linear regression: $y=0.010 x-17.4, r^{2}=0.78$. Vertical bar represents LSD $=0.27$

1995). Even with modern molecular techniques it is difficult to distinguish different tomato cultivars (Miller and Tanksley 1990; Park et al. 2004). Genetic variation is essential to plant breeders as a basis for crop improvement. Therefore, breeders will have to utilize alternative sources of variation. As the genetic variation within modern cultivars is only a fraction of the variation between Lycopersicon species, these wild species offer opportunities for breeding (Miller and Tanksley 1990). Especially Lycopersicon species which are chilling resistant and capable of growing at high altitudes (e.g. L. hirsutum), offer opportunities for the identification of favorable gene loci, connected with growth at sub-optimal temperature, and subsequent introgression of these genes into cultivated tomato (Venema et al. 2005).

\section{Conclusions}

Although tomato breeding did increase yield significantly in the past 50 years, yields at present day greenhouse conditions seem to have reached a plateau level. Therefore, for breeding to be able to increase energy efficiency it is important to study possibilities of breeding cultivars that reach similar or

Table 5 Cultivar differences in stem length, total number of leaves produced (NoL), number of trusses (NoT) and total number of fruits produced per plant $(\mathrm{NoF})$ at final harvest stage in three experiments

\begin{tabular}{|c|c|c|c|c|c|}
\hline Exp. & Cultivar & $\begin{array}{l}\text { Stem length } \\
\left(\mathrm{m} \text { plant }^{-1}\right)\end{array}$ & NoL $\left(\right.$ plant $\left.^{-1}\right)$ & NoT $\left(\right.$ plant $^{-1}$ ) & NoF $\left(\right.$ plant $\left.^{-1}\right)$ \\
\hline \multirow[t]{5}{*}{1} & Counter & $5.27 \mathrm{a}$ & $70 \mathrm{~b}$ & $19.7 \mathrm{~b}$ & $142 \mathrm{~b}$ \\
\hline & Pronto & $5.71 \mathrm{c}$ & $71 \mathrm{~b}$ & $19.3 \mathrm{~b}$ & $132 \mathrm{a}$ \\
\hline & Chaser & $5.30 \mathrm{ab}$ & $66 \mathrm{a}$ & $18.3 \mathrm{a}$ & $125 \mathrm{a}$ \\
\hline & Prospero & $5.49 \mathrm{ab}$ & $64 \mathrm{a}$ & $17.8 \mathrm{a}$ & $128 \mathrm{a}$ \\
\hline & $F$-prob. $^{\text {a }}$ & 0.007 & 0.006 & $<0.001$ & 0.005 \\
\hline \multirow[t]{4}{*}{2} & Capita & 4.86 & 60 & 15.8 & 111 \\
\hline & Chaser & 4.57 & 57 & 15.3 & 103 \\
\hline & Prospero & 4.84 & 56 & 15.5 & 102 \\
\hline & $F$-prob. ${ }^{\mathrm{a}}$ & 0.215 & 0.070 & 0.592 & 0.161 \\
\hline \multirow[t]{8}{*}{3} & Moneymaker & $4.71 \mathrm{a}$ & 67 & $16.8 \mathrm{a}$ & $118 \mathrm{ab}$ \\
\hline & Extase & $4.95 \mathrm{~b}$ & 63 & $17.9 \mathrm{bc}$ & $126 \mathrm{~b}$ \\
\hline & Calypso & $5.08 \mathrm{bc}$ & 64 & $17.6 \mathrm{ab}$ & $111 \mathrm{a}$ \\
\hline & Liberto & $5.33 \mathrm{~d}$ & 69 & $18.5 \mathrm{bc}$ & $125 \mathrm{~b}$ \\
\hline & Gourmet & $5.85 \mathrm{e}$ & 67 & $18.6 \mathrm{c}$ & $127 \mathrm{~b}$ \\
\hline & Chaser & $5.34 \mathrm{~d}$ & 65 & $17.8 \mathrm{abc}$ & $117 \mathrm{ab}$ \\
\hline & Encore & $5.19 \mathrm{~cd}$ & 66 & $16.9 \mathrm{a}$ & $107 \mathrm{a}$ \\
\hline & $F$ - prob. $^{\mathrm{a}}$ & $<0.001$ & 0.053 & 0.007 & 0.014 \\
\hline
\end{tabular}

Values are the averages for 2 temperature regimes

a $F$-probability (significant levels $<0.05$ presented in bold). Different letters within an experiment indicate significant differences between treatments based on Student's $t$-test $(P=0.05)$ 
higher yields at sub-optimal temperatures. As variation in temperature response between elite cultivars is limited (no genotype $\times$ temperature interaction in these experiments) it is important that other resources, e.g. wild relatives, are utilized. The main effects of reduced temperature occur during early stages of crop growth, resulting in a later start of production and a lower early production. However on the long term total yield, biomass production and partitioning were not affected by temperature. Thus, one important aspect to consider when breeding for energy efficient cultivars is earliness.

Acknowledgements This work was performed as part of a Dutch research program, entitled "Rassen onder Glas met minder Gas", aiming at breeding more energy-efficient greenhouse crops. This programme is financially supported by the Dutch Horticultural Board (Productschap Tuinbouw), The Dutch Organisation for Energy and Environment (NOVEM), the Ministry of Agriculture, Nature and Food Quality (LNV) and several private breeding companies.

\section{References}

Adams SR, Cockshull KE, Cave CRJ (2001) Effect of temperature on the growth and development of tomato fruits. Ann Bot 88:869-877

CBS (2006) The Netherlands. http://statline.cbs.nl. Cited 1 Nov 2006

Cheniclet C, Rong WY, Causse M, Frangne N, Bolling L, Carde JP, Renaudin JP (2005) Cell expansion and endoreduplication show a large genetic variability in pericarp and contribute strongly to tomato fruit growth. Plant Physiol 139:1984-1994

De Koning ANM (1989) The effect of temperature on fruit growth and fruit load of tomato. Acta Horticult 248:329336

De Koning ANM (1994) Development and dry matter distribution in glasshouse tomato: a quantitative approach. $\mathrm{Ph} . \mathrm{D}$. Thesis, Wageningen Agricultural University, Wageningen, The Netherlands

Elings A, Kempkes FLK, Kaarsemaker RC, Ruijs MNA, van de Braak NJ, Dueck TA (2005) The energy balance and energy-saving measures in greenhouse tomato cultivation. Acta Horticult 691:67-74

Hay RKM (1995) Harvest Index - a review of its use in plant breeding and crop physiology. Ann Appl Biol 126:197216

Heuvelink E (1995) Effect of temperature on biomass allocation in tomato (Lycopersicon esculentum). Physiol Plant 94:447-452

Heuvelink E (1997) Effect of fruit load on dry matter partitioning in tomato. Sci Horticult 69:51-59

Heuvelink E, Buiskool RPM (1995) Influence of sink-source interaction on dry matter production in tomato. Ann Bot 75:381-389
Ho LC (1996a) The mechanism of assimilate partitioning and carbohydrate compartmentation in fruit in relation to the quality and yield of tomato. J Exp Bot 47:1239-1243

Ho LC (1996b) Tomato. In: Zamski E, Schaffer AA (eds) Photoassimilate distribution in plants and crops: sourcesink relationships. Dekker, New York, pp 709-728

Ho LC, Hewitt JD (1986) Fruit development. In: Atherton JG, Rudich J (eds) The tomato crop. A scientific basis for improvement. Chapman \& Hall, London, UK, pp 201-239

Hurd RG, Graves CJ (1985) Some effects of air and root temperatures on the yield and quality of glasshouse tomatoes. J Horticult Sci 60:359-371

Khayat E, Ravad D, Zieslin N (1985) The effects of various night-temperature regimes on the vegetative growth and fruit production of tomato plants. Sci Horticult 27:9-13

KWIN (1998) Proefstation voor de bloemisterij en glasgroente (PGB). Kwantitatieve informatie voor de glastuinbouw, 1998-1999

Lindhout P (2005) Genetics and breeding. In: Heuvelink E (ed) Tomatoes. CABI Publishing, Wallingford, UK, pp 21-52

Milach SCK, Federizzi LC (2001) Dwarfing genes in plant improvement. Adv Agron 73:35-63

Miller JC, Tanksley SD (1990) RFLP analysis of phylogenetic relationships and genetic variation in the genus Lycopersicon. Theor Appl Genet 80:437-448

Morrison MJ, Voldeng HD, Cober ER (1999) Physiological changes from 58 years of genetic improvement of shortseason soybean cultivars in Canada. Agron J 91:685-689

Park YH, West MAL, St Clair DA (2004) Evaluation of AFLPs for germplasm fingerprinting and assessment of genetic diversity in cultivars of tomato (Lycopersicon esculentum L.). Genome 47:510-518

Paul EMM, Hardwick RC, Parker PF (1984) Genotypic variation in the response to suboptimal temperatures of growth in tomato (Lycopersicon esculentum Mill). New Phytol 98:221-230

Peet MM, Welles GWH (2005) Greenhouse tomato production. In: Heuvelink E (ed) Tomatoes. CABI Publishing, Wallingford, UK, pp 257-304

Rick CM, Chetelat RT (1995) Utilization of related wild species for tomato improvement. Acta Horticult 412:21-38

Smeets L, Garretsen F (1986) Growth analyses of tomato genotypes grown under low night temperatures and low light-intensity. Euphytica 35:701-715

Van de Vooren J, Welles GWH, Hayman G (1986) Glasshouse crop production. In: Atherton JG, Rudich J (eds) The tomato crop. A scientific basis for improvement. Chapman and Hall, London, UK, pp 581-623

Van der Knijff A, Benninga J, Reijnders C (2004) LEI. Energie in de glastuinbouw. Ontwikkelingen in de sector en op bedrijven $\mathrm{t} / \mathrm{m}$ 2003:65

Van der Ploeg A, Heuvelink E (2005) Influence of sub-optimal temperature on tomato growth and yield: a review. J Horticult Sci Biotechnol 80:652-659

Venema JH, Linger P, Van Heusden AW, Van Hasselt PR, Bruggemann W (2005) The inheritance of chilling tolerance in tomato (Lycopersicon spp.). Plant Biol 7:118-130

Whitehead SJ, Summerfield RJ, Muehlbauer FJ, Coyne CJ, Ellis RH, Wheeler TR (2000) Crop improvement and the accumulation and partitioning of biomass and nitrogen in lentil. Crop Sci 40:110-120 